\title{
Pengaruh Partisipasi Anggaran Terhadap Kinerja Manajerial Dengan Komitmen Organisasi Sebagai Variabel Moderating Pada Rumah Sakit Pekanbaru
}

\author{
FAIZAH KAMILAH \\ Fakultas Ekonomi Universitas Lancang Kuning \\ Jl. YosSudarso KM 8Rumbai \\ Telp.(0761) 52581 email : faizahkamilah76@yahoo.com
}

\begin{abstract}
This study was conducted using a survey method to Hospitals in the city of Pekanbaru. This study aims to examine the effect of budget participation on managerial performance and organizational commitment as moderating variable in the hospital in Pekanbaru. The population in this study was 21 Hospital in Pekanbaru. Data collected by distributing questionnaires to 84 respondents, but only 80 questionnaires that can be used in this study. The type of data used are primary data to the data collection method using a questionnaire. Data analysis method used in this study is multiple regression (multiple regression). These results indicate that the effect of budget participation on managerial performance with 0.002 significance (alpha 0.05). Organizational commitment can moderate the effect of budget participation on managerial performance with a significance of 0.000 (alpha 0.05).
\end{abstract}

Keywords: Budget Participation, Organizational Commitment, Manajerial Performance.

Kinerja manajerial merupakan salah satu faktor yang dapat meningkatkan keefektifan organisasional. Dengan melakukan pengukuran kinerja maka dapat memastikan apakah pengambilan keputusan dilakukan secara tepat dan objektif. (Bastian 2005). Kinerja manajerial dipengaruhi oleh beberapa faktor seperti partisipasi penyusunan anggaran, komitmen organisasi, gaya kepemimpinan barorientasi tugas, gaya kepemimpinan berorientasi hubungan dan sebagainya. Dari beberapa hasil penelitian terdahulu, terbukti bahwa variabel partisipasi penyusunan anggaran lebih banyak diteliti pengaruhnya terhadap kinerja manajerial. Hal ini dikarenakan anggaran mempunyai dampak langsung terhadap manusia terutama bagi yang terlibat didalam penyusunan anggaran (Siegel dan Marconi, 1989). Adanya keterlibatan manajer dalam penyusunan anggaran yang biasa disebut dengan penyusunan anggaran secara partisipatif maka kinerja manajerial akan lebih meningkat (Milani, 1975).

Peran partisipasi penyusunan anggaran sebagai variabel yang secara langsung dapat mempengaruhi kinerja manajerial telah dibuktikan oleh penelitian yang dilakukan oleh Brownell dan McInnes (1986), Yusfaningrum dan Ghozali (2005). Namun Beberapa penelitian yang lain tidak menemukan bukti bahwa partisipasi penyusunan anggaran mempunyai pengaruh terhadap kinerja manajerial (Kenis, 1979, Brownel and Hirst, 1986, Sinuraya, 2009). Ketidak konsistenan hasil penelitian terutama mengenai peranan variabel partisipasi penyusunan anggaran sebagai variabel independen yang dapat langsung mempengaruhi kinerja manajerial menyebabkan penelitian lebih lanjut mengenai partisipasi penyusunan anggaran.

Pengaruh penganggaran partisipasi pada kinerja manajerial merupakan tema yang menarik dalam penelitian akuntansi manajemen. Brownell (1986) menyebutkan dua alasan yaitu: (a) partisipasi dinilai sebagai pendekatan manajerial yang dapat meningkatkan kinerja anggota organisasi, dan (b) berbagai penelitian yang menguji hubungan antara partisipasi dan kinerja hasilnya saling bertentangan.

Govindarajan dalam Supriyono (2005) menyatakan bahwa untuk mengatasi 
ketidakkonsistenan hasil-hasil riset tersebut, diperlukan pendekatan kontinjensi (Contingency). Pendekatan ini memberikan suatu gagasan bahwa hubungan antara partisipasi penganggaran dan kinerja manajerial diduga dipengaruhi oleh faktor atau variabel yang bersifat kondisional.

Variabel komitmen organisasi adalah variabel yang dapat memoderasi hubungan antara partisipasi penyusunan anggaran dengan kinerja manajerial. Komitmen organisasi merupakan dorongan dari dalam individu untuk berbuat sesuatu agar dapat menunjang keberhasilan organisasi sesuai dengan tujuan yang telah direncanakan dan tidak lebih mengutamakan kepentingannya sendiri (Weiner, dalam Corynata, 2004). Untuk itulah dalam penelitian ini menggunakan variabel moderasi komitmen organisasi.

Ghozali dan Yusfaningrum (2005) melakukan penelitian tentang analisis pengaruh partisipasi anggaran terhadap kinerja manajerial melalui komitmen tujuan anggaran dan job relevant information sebagai variabel intervening. Penelitian ini menunjukkan partisipasi anggaran berpengaruh positif dan signifikan terhadap kinerja manajerial.

Komitmen organisasi sangat penting pengaruhnya terhadap pekerjaan agar tercipta kondisi kerja yang kondusif sehingga organisasi dapat berjalan secara efektif dan efisien. Dapat dikatakan bahwa komiten adalah kerelaan untuk bekerja keras dan memberikan energi serta waktu untuk sebuah pekerjaan atau aktivitas. Komitmen organisasi yang kuat akan mendorong individu berusaha keras mencapai tujuan organisasi. Partisipasi anggaran akan menimbulkan adanya kecukupan anggaran dan kemudian mempengaruhi kinerja (Randall, 1990 dalam Sumarno, 2005).

Sardjito dan Muthaher (2007) melakukan penelitian tentang pengaruh partisipasi anggaran terhadap kinerja aparat pemerinatah daerah dengan budaya organisasi dan komitmen organisasi sebagai variabel moderating. Penelitian ini menunjukkan terdapat pengaruh yang signifikan antara komitmen organisasi dalam memoderasi partisipasi penyusunan anggaran terhadap kinerja aparat pemerintah daerah. Hasil ini menunjukkan semakin tinggi komitmen organisasi akan menyebabkan peningkatan kerja aparat pemerintah daerah dalam berpartisipasi penyusunan anggaran.

Rumah sakit adalah bagian integral dari suatu organisasi sosial dan kesehatan dengan fungsi menyediakan pelayanan kesehatan paripurna, kurarif dan preventif kepada masyarakat serta pelayanan rawat jalan yang diberikannya. Rumah sakit juga merupakan pusat pendidikan dan pelatihan bio medik (Bastian, 2007).

Rumah Sakit terdiri dari rumah Sakit pemerintah dan swasta. Pada rumah sakit pemerintah sebagian besar dimiliki oleh pemerintah daerah, sedangkan pada rumah sakit swasta yang bergerak dibidang jasa pelayanan publik merupakan bagian dari dua bisnis yang berorientasikan pada keuntungan. Upaya meningkatkan mutu pelayanan terbaik dan untuk memperbaiki standar pelayanan, manajemen di rumah sakit perlu memperhatikan kinerja pencapaian unit-unit pelaksana pelayanan kesehatan tersebut. Salah satu upaya mengalokasikan sumber daya rumah sakit dalam pengendalian kinerja pelayanan rumah sakit adalah sistem anggaran. Kebanyakan rumah sakit yang merupakan keuangan publik masih mengandalkan sistem anggaran tradisional dalam perencanaan anggarannya. Sistem anggaran tradisional ini memiliki wujud seperti berorientasi pada input, tidak terkait dengan perencanaan jangka panjangdan bersifattahunan(Bastian, 2005). Sistem anggaran rumah sakit berorientasi pada kinerja (performance budgeting) merupakan upaya terobosan prinsip anggaran tradisional yang kerap dilakukan. Walaupun ada kesulitan dalam menentukan output measurement, sistem anggaran ini dapat diandalkan dalam reformasi keuangan rumah sakit karena memiliki banyak kelebihan dalam akuntabilitas keuangan rumah sakit.

Selanjutnyaakandibahastentangkinerj amanajerial. Kinerja manajerial merupakan salah satu faktor yang dapat meningkatkan 
keefektifan organisasional. Mahoney et.al dalam Sumadiyah dan Susanta (2004) melihat kinerja manajer berdasar pada kemampuan manajer dalam melaksanakan tugas manajerialnya. Kinerja manajerial meliputi kemampuan manajer dalam: perencanaan, investigasi, pengkoordinasian, evaluasi, pengawasan, pemilihan staff, negoisasi, perwakilan dan kinerja secara menyeluruh telah ditetapkan. Menurut Bastian (2005) menyatakan bahwa setiap organisasi biasanya tertarik pada pengukuran kinerja dalam aspek berikut : 1) Aspek finansial, Aspek ini meliputi anggaran atau cash flow. Aspek finansial ini sangat penting diperhatikan dalam pengukuran kinerja, sehingga kondisi keuangan dapat dianalogikan sebagai aliran darah dalam tubuh manusia; 2) Kepuasan pelanggan, Dalam globalisasi perdagangan, peran dan posisi pelanggan sangat krusial dalam penentuan strategi perusahaan. Untuk itu jika dikaitkan dengan pemerintahan, maka yang dilihat adalah kepuasan masyarakat dan bagaimana pemerintah memberikan pelayanan kepada msyarakat; 3) Operasi dan bisnis internal, Informasi operasi bisnis internal diperlukan untuk memastikan bahwa seluruh kegiatan organisasi untuk mencapai tujuan dan sasaran organisasi yang tercantum dalam skema strategis; 4) Kepuasan pegawai Dalam organisasi yang banyak melakukan inovasi, peran strategis pegawai sungguh sangat nyata; 5) Kepuasan komunitas dan shareholders/ stakeholders

Pengukuran kinerja perlu didesain unutk mengakomodasikan kepuasan dari para stakeholders; 6) Waktu, Ukuran waktu juga merupakan variabel yang perlu diperhatikan dalam desain pengukuran kinerja, sehingga informasi yang dibutuhkan diharapkan relevan dan up to date.

Menurut Supriyono penganggaran partisipatif adalah suatu proses penyusunan anggaran yang melibatkan setiap manajer pusat pertanggung jawaban dan mereka memiliki kesempatan untuk menjelaskan dan memberikan alasan atas anggaran yang diusulkan. Partisipasi penganggaran didefinisikan sebagai suatu proses dimana kinerja individu akan dievaluasi, diberikan penghargaan, atau hukuman berdasarkan dari tingkat pencapaian target anggarannya (Chong dan Johnson, 2007).

Komitmen organisasi menurut Weiner dalam Suryanawa (2008) adalah dorongan dari dalam individu untuk berbuat sesuatu agar dapat menunjang keberhasilan organisasi sesuai dengan tujuan dan lebih mengutamakan kepentingan organisasi dibandingkan dengan kepentingan sendiri.

Soemarno (2005), Supriyono (2004), Suardana dan Suryanawa (2008), Corynta (2004), Sardjito dan Muthaher (2007), Putu dan Wayan (2009), menyatakan partisipasi penyusunan anggaran berpengaruh terhadap kinerja manajerial dan partisipasi penyusunan anggaran dengan dimoderasi oleh komitmen organisasi berpengaruh terhadap kinerja manajerial. Sedangkan Supriyono (2004), Suardana dan Suryanawa (2008) menyatakan partisipasi penyusunan anggaran dengan dimoderasi oleh komitmen organisasi tidak berpengaruh terhadap kinerja manajerial.

\section{METODE}

Metode penelitian yang digunakan adalah penelitian kuantitatif, dengan populasi dalam penelitian ini 21 rumah sakit di Pekanbaru. Pengambilan sampel dilakukan dengan menggunakan metode purposive sampling. Sedangkan responden dalam penelitian ini yaitu manajer tingkat menengah dan manajer tingkat bawah dari Rumah Sakit yang ada di Pekanbaru yaitu Manajer Keuangan, Manajer Pemasaran, Manajer Operasional dan Manajer Sumber Daya Manusia (SDM). Data penelitian yang digunakan adalah data primer, yaitu data yang dikumpulkan dengan mengirimkan kuesioner atau daftar pertanyaan kepada para manajer di rumah sakit yang ada di Pekanbaru. Teknik analisis data dengan menggunakan regresi dengan variabel moderating digunakan uji interaksi yang merupakan aplikasi khusus regresi berganda linear. 


\section{HASIL}

Penelitian ini menggunakan kuesioner untuk pengumpulan data yang dikirimkan kepada manajer rumah sakit Pekanbaru. Pengiriman daftar pertanyaan diantar langsung untuk menjaga kepastian sampainya daftar pertanyaan ke tangan responden. Dari 84 kuesioner yang dikirimkan, kuesioner yang kembali sebanyak 80 (95\%). Kuesioner yang dapat diolah sebanyak 80 (95\%).

Dalam penelitian ini untuk menilai kinerja manajerial digunakan 15 pertanyaan. Total skor jawaban responden diperoleh sebesar 6231 dengan nilai minimal sebesar 3600 , nilai maksimal sebesar 8400 , dan ratarata skor sebesar 5,2 dan kriteria posisi sebesar $74,17 \%$. Kriteria $74,17 \%$ termasuk di posisi $69 \%-83 \%$ (sangat baik).

Dalam penelitian ini untuk menilai partisipasi anggaran digunakan 6 pertanyaan. Total skor jawaban responden diperoleh sebesar 2501 dengan nilai minimal sebesar 1920, nilai maksimal sebesar 3360, dan ratarata skor sebesar 5,21 dan Kriteria posisi sebesar $74,43 \%$. Kriteria $74,43 \%$ termasuk di posisi $69 \%$ - $83 \%$ (sangat baik).

Dalam penelitian ini untuk menilai komitmen organisasi digunakan 9 pertanyaan. total skor jawaban responden diperoleh sebesar 3974 dengan nilai minimal sebesar 2160, nilai maksimal sebesar 5040, dan ratarata skor sebesar 5,52 dan kriteria posisi sebesar $78,85 \%$. Kriteria 78,85\% termasuk di posisi $69 \%$ - $83 \%$ (sangat baik).

Persamaan regresi yang diperoleh dari hasil pengujian hipotesis pertama adalah sebagai berikut : $\mathrm{Y}=55,024+0,871 \mathrm{X}_{1}$; Persamaan regresi yang diperoleh dari hasil pengujian hipotesis kedua adalah sebagai berikut : $\mathrm{Y}=4,553+0,055 \mathrm{X}_{1}+0,199 \mathrm{X}_{2}+$ $0,079 \mathrm{X}_{1} \mathrm{X}_{2}$

Dari hasil uji kooefisien determinasi untuk hipotesis pertama diperoleh nilai sebesar 0.699. Angka ini menjelaskan bahwa 69\% kinerja manajerial dipengaruhi partisipasi anggaran sedangkan sisanya $31 \%$ kinerja manajerial dijelaskan oleh variabel lainnya, seperti wewenang, kecukupan anggaran, budaya organisasi, komitmen tujuan anggaran, desentralisasi, locus of control dan lain-lain.

Dari hasil uji kooefisien determinasi untuk hipotesis kedua sebesar 0,655 (65\%).Angka ini menjelaskan bahwa dengan nilai persentase masing-masing hipotesis tersebut kinerja manajerial dipengaruhi partisipasi anggaran, komitmen organisasi. Sedangkan sisanya untuk hipotesis pertama sebesar 31\%, hipotesis kedua sebesar $35 \%$ dijelaskan oleh variabel seperti seperti wewenang, kecukupan anggaran, budaya organisasi, komitmen tujuan anggaran, desentralisasi, locus of control dan lain-lain.

\section{PEMBAHASAN}

\section{Partisipasi Penyusunan Anggaran Berpengaruh Terhadap Kinerja Manajerial}

Hasil pengolahan data diketahui t hitung $(13,472)>\mathrm{t}$ tabel $(1,990)$ dan nilai signifikan sebesar 0,002 dengan tingkat kesalahan (alpha) sebesar 0.05. Oleh karena itu dapat disimpulkan bahwa partisipasi anggaran berpengaruh signifikan terhadap kinerja manajerial.

Hal ini sejalan dengan pendapat yang mengatakan anggaran yang telah disusun memiliki peranan sebagai perencanaan dan sebagai kriteria kinerja, yaitu anggaran dipakai sebagai suatu sistem pengendalian untuk mengukur kinerja manajer. Untuk mencegah dampak fungsional atau disfungsionalnya, sikap dan perilaku anggota organisasi dalam penyusunan anggaran, perlu melibatkan manajemen pada level yang lebih rendah sehingga anggaran partisipatif dapat dinilai sebagai pendekatan manajerial yang dapat meningkatkan kinerja setiap anggota organisasi (Sardjito dan Muthaher, 2007).

Diperkuat oleh Supriyono (2005) yang mengungkapkan bahwa di Indonesia, hubungan antara partisipasi anggaran dengan kinerja manajer mempunyai hubungan positif secara signifikan. Manajer yang memiliki partisipasi anggaran yang tinggi akan lebih memahami tujuan anggaran. Karena kinerja manajer akan dinilai berdasarkan target 
anggaran yang bisa dicapai, manajer akan bersungguh-sungguh dalam penyusunan anggaran dan menyebabkan meningkatnya kinerja manajer tersebut.

\section{Komitmen Organisasi berpengaruh terhadap hubungan partisipasi anggaran dengan kinerja manajerial}

Hasil pengolahan data diketahui t hitung $(5,091)>t$ tabel $(1,990)$ dan nilai signifikan sebesar 0,000 dengan tingkat kesalahan (alpha) sebesar 0.05. Oleh karena itu dapat disimpulkan bahwa partisipasi anggaran yang dimoderasi oleh komitmen organisasi berpengaruh signifikan terhadap kinerja manajerial.

Hal ini sejalan dengan pendapat yang mengatakan komitmen organisasi adalah dorongan dari dalam individu untuk berbuat sesuatu agar dapat menunjang keberhasilan organisasi sesuai dengan tujuan dan lebih mengutamakan kepentingan organisasi dibandingkan dengan kepentingan sendiri. Dorongan yang ada pada setiap individu dapat mempengaruhi keberhasilan suatu organisasi, jika individu tersebut berpartisipasi dalam penyusunan anggaran akan turut meningkatkan kinerja manajerial (Bambang Sradjito dan Osmad Muthaher, 2007).

Juga didukung oleh pendapat Wiener dalam Juli dan Suryanawa (2010) mendefinisikan komitmen organisasi sebagai dorongan dari dalam diri individu untuk berbuat sesuatu agar dapat menunjang keberhasilan organisasi sesuai dengan tujuan dan lebih mengutamakan kepentingan organisasi dibandingkan kepentingan sendiri. Dalam pandangan ini, individu yang memiliki komitmen yang tinggi akan lebih mengutamakan kepentingan organisasi nya dari pada kepentingan pribadi atau kelompoknya. Komitmen akan membuat organisasi lebih produktif dan profitable. Bagi individu dengan komitmen organisasi yang tinggi, pencapaian tujuan organisasi merupakan hal penting.

\section{SIMPULAN}

Berdasarkan hasil uji dari hipotesis pertama dapat dilihat bahwa partisipasi penyusunan anggaran berpengaruh signifikan terhadap kinerja manajerial, dengan melihat signifikansi sebesar $0,002 \quad(0,002<0,05)$. Berdasarkan hasil uji hipotesis kedua dapat dilihat bahwa komitmen organisasi berpengaruh terhadap hubungan antara partisipasi penyusunan anggaran dengan kinerja manajerial. Hal ini dibuktikan dengan nilai signifikansi sebesar $0,000(0,000<0,5)$.

Berdasarkan hasil koefisien determinasi untuk hipotesis pertama diperoleh nilai koefisien determinasi sebesar 0.696. Angka ini menjelaskan bahwa 69\% kinerja manajerial dipengaruhi partisipasi anggaran sedangkan sisanya $31 \%$ kinerja manajerial dijelaskan oleh variabel lainnya, seperti wewenang, kecukupan anggaran, budaya organisasi, komitmen tujuan anggaran, desentralisasi, locus of control dan lain-lain.

Berdasarkan hasil koefisien determinasi untuk hipotesis kedua sebesar 0,656 (65\%). Angka ini menjelaskan bahwa dengan nilai persentase masing-masing hipotesis tersebut kinerja manajerial dipengaruhi partisipasi anggaran, komitmen organisasi. Sedangkan sisanya untuk hipotesis pertama sebesar 31\%, hipotesis kedua sebesar 35\%dijelaskan oleh variabel seperti seperti wewenang, kecukupan anggaran, budaya organisasi, komitmen tujuan anggaran, desentralisasi, locus of control dan lain-lain.

\section{DAFTAR RUJUKAN}

Anthony, Robert N. dan Govindanrajan, Vijay. 2005. Sistem Pengendalian Manajemen. Edisi 1. Salemba Empat. Jakarta.

Bambang Sardjito dan Osmad Muthaher. 2007. Pengaruh Partisipasi Penyusunan Anggaran Terhadap Kinerja Aparat Pemerintah Daerah : Budaya Organisasi Dan Komitmen Organisasi Sebagai Variabel 
Moderating. Simposium Nasional AkuntansiX. Makasar.

Brownell, P. and McInnes, M. 1986. "Budgetary Participation, motivation, and manajerial performance". The Accounting Review, Vol. 61, No. 4.

Chong, Vincent K. dan Kar Ming Chong. 2002. Budget Goal Commitment and Informational Effects of Budget Participation on Performance": AstructuralEquation Modeling Approach, Behavioral Research in Accounting. USA.

Daft, Richard L. 2010. Era Baru Manajemen. Buku 2. Edisi 9. Salemba Empat. Jakarta.

Ghozali, Imam. 2005. Aplikasi Analisis Multivariat dengan Program SPSS. Universitas Diponegoro. Semarang.

Govindarajan V,1986. Impact of Participation in The Budgetary Process on Managerial Attitudes and Performance. Universalistic and Contigency Perspective. Decision Sciences 17. pp. 496-516.

Indra, Bastian. 2005. Akuntansi Sektor Publik. Yogyakarta. BPFE.

Lubis, Arfan Ikhsan. 2010. Akuntansi Keperilakuan. Salemba Empat. Jakarta.

Mahoney, T. A, Jerdee and S.J Carroll. 1963. Development of managerial performance. A Research Approach. Cincinnati. Ohio: South Western Publishing Co.

Milani, Ken. 1975. The Relationship of Participation in Budget Setting to Industrial Supervisor Performance and Attitudes : A Field Study, The Accounting Review.

Mowday, R.T, R. M Steers and L. W Porter. 1979. The Measurement of
Organizational Commitment. Journal of Vocational Behaviour.

Nor, Wahyudin. 2007. Desentralisasi dan Gaya Kepemimpinan Sebagai Variabel Moderating Dalam Hubungan Antara Partisispasi Penyusunan Anggaran dan Kinerja Manajerial. Simposium Nasional Akuntansi X. Makasar.

Ridwan dan Sunarto. 2010. Rumus dan Data Dalam Analisis Statistika. Alfabeta. Bandung.

Suardana, Kadek Juli dan Ketut Suryanawa. 2010. Pengaruh Partisipasi Penyusunan Anggaran Pada Kinerja Manajerial Dengan Komitmen Organisasi Sebagai Variabel Moderasi. Denpasar: Vol. 5 Edisi 1.

Sumadiyah dan Susanta. 2004. Job Relevant Information (JRI) dan Ketidakpastian Lingkungan dalam Hubungan Partisipasi Anggaran dan Kinerja Manajerial. Jurnal Ekonomi dan Bisnis Indonesia.

Sumarno, J. 2005. Pengaruh Komitmen Organisasi dan Gaya Kepemimpinan terhadap Hubungan antara Partisipasi Anggaran dan Kinerja Manajerial. Simposium Nasional Akuntansi VIII. Solo.

Supriyono, R.A. 2005. Pengaruh Komitmen Organisasi, Keinginan Sosial, dan Asimetri Informasi terhadap Hubungan Antara Partisipasi Penganggaran dengan Kinerja Manajer. Jurnal Ekonomi dan Bisnis Indonesia.

Thoha, Miftah. 2008. Perilaku Organisasi Konsep Dasar dan Aplikasinya. PT Raja Grafindo Persada. Jakarta.

Vincent K, Chong dan Dareen M. Jhonson. 2007. Testing A Model of The Antecendents nad Consequences of Budgetary Participation on Job Performance. Accounting and Business Research, 37 (1). h: 3-19. 